\title{
Apresentaçáo
}

\section{Comunicação e Filosofia}

Carlos Moreno

Editor geral da Logos. Doutor em Semiologia pela UFRJ. Professor do Departamento de Relações Públicas da Faculdade de Comunicação Social da Universidade do Estado do Rio de Janeiro.

Karl Jaspers, em 1964, escreveu que o "objetivo do pensar filosófico é levar a uma forma de pensamento capaz de iluminar-nos interiormente e de iluminar o caminho diante de nós, permitindo-nos apreender o fundamento onde encontraremos significado e orientação". Certamente é nessa trilha que seguem os autores reunidos no dossiê Comunicação e Filosofia. Jorge Cardoso Filho busca mapear o desenvolvimento de tendências no campo da Comunicação brasileira em função da estética e da hermenêutica filosófica, recorrendo aos filósofos Martin Heidegger e Martin Seel. Com base na crítica nietzchiana do sujeito, o artigo de Silvia Pimenta Velloso Rocha pretende analisar mecanismos de produção de si presentes nas sociedades midiáticas contemporâneas como uma manifestação de niilismo. Paulo Bernardo Vaz e Renné Oliveira França abordam a construção de sentido frente a um acontecimento e, para tal, partem de conceitos do filósofo Gilles Deleuze e do sociólogo Louis Quéré. Ângela Cristina Salgueiro Marques explica como processos comunicativos ético-morais ganham concretude por meio da linguagem na experiência intersubjetiva. Uma reflexão sobre a potencialidade do modelo praxiológico da Comunicação para analisar a construção das celebridades na cena midiática contemporânea é o objetivo de Paula Guimaráes Simóes. Fátima Régis e sete de seus orientandos investigam se as transformaçóes que as tecnologias digitais engendraram no sistema da mídia exigem novas competências cognitivas para a fruição dos seriados de televisão. Finalmente, Maria Cláudia Tardin Pinheiro tem como objetivo assinalar as pressóes sociais e os valores culturais que participam do processo de construção de identidades brasileiras na sociedade hipermoderna metropolitana, por meio da análise do universo publicitário.

Para concluir, ainda a lição de Jaspers. "A filosofia é universal. Nada existe que a ela não diga respeito. Quem se dedica a filosofar interessa-se por tudo.”

Boa leitura. 